\title{
Influence of Live Yeast Culture (Saccharomyces cerevisiae) on Milk Production and Composition, and Blood Biochemistry of Grazing Dairy Ewes during the Milking Period
}

\author{
T. MAŠEK ${ }^{1}$, Ž. MIKULEC ${ }^{1}$, H. VALPOTIĆ ${ }^{1}$, N. ANTUNAC $^{2}$, N. MIKULEC ${ }^{2}$, \\ Z. STOJEVIĆ ${ }^{3}$, N. FILIPOVIĆ ${ }^{3}$, S. PAHOVIĆ ${ }^{4}$
}
${ }^{1}$ Department of Animal Nutrition, Faculty of Veterinary Medicine, University of Zagreb, Zagreb, Croatia
${ }^{2}$ Dairy Department, Faculty of Agriculture, University of Zagreb, Zagreb, Croatia
${ }^{3}$ Department of Physiology, Faculty of Veterinary Medicine, University of Zagreb, Zagreb, Croatia
${ }^{4}$ Veterinary Ambulance, Poreč, Croatia

Received September 3, 2007

Accepted June 11, 2008

\begin{abstract}
Mašek T., Ž. Mikulec, H. Valpotić, N. Antunac, N. Mikulec, Z. Stojević, N. Filipović, S. Pahović: Influence of Live Yeast Culture (Saccharomyces cerevisiae) on Milk Production and Composition, and Blood Biochemistry of Grazing Dairy Ewes during the Milking Period. Acta Vet. Brno 2008, 77: 547-554.

A feeding trial was conducted to evaluate the influence of live yeast culture (Saccharomyces cerevisiae) on milk production, composition, and blood biochemistry of dairy ewes during the machine milking period.

The control group (CD) was fed a concentrate mixture and hay and grazed twice daily, while the second (YS3) and third (YS6) groups were fed the same diet supplemented with 3 or $6 \mathrm{~g}$ of live yeast culture (Yea Sacc ${ }^{1026}$ ), respectively. The treated groups had significantly higher values $(p<0.05)$ for fat corrected milk (FCM) $(1221,1116$ and $940 \mathrm{~g} /$ day, for YS6, YS3 and CD group, respectively) and fat-protein corrected milk (FPCM) (1204, 1103 and 931 g/day, for YS6, YS3 and CD group, respectively), while the values for milk yield, fat yield and lactose yield were higher $(p<0.05)$ only in the YS6 group compared to the CD group. Milk yield values were constantly higher in the YS6 group than in the control group while the values for the YS3 group were more variable during milking. Milk composition was not significantly affected by yeast supplementation with the exception of urea values which were lower $(p<0.05)$ in the YC6 group. Yeast administration influenced $\beta$-hydroxy-butyrate (BHB) values, which were higher $(p<0.05)$ in the treated groups; and non-esterified fatty acids (NEFA) values, which were higher $(p<0.05)$ only in the YS6 group compared to the control group. Other blood biochemistry values were not influenced by the treatments.

We conclude that supplementation with live yeast culture, under the conditions of our experiment, had a significant effect on the performance and metabolism of grazing dairy ewes during the machine milking period. Based on more constant results, we could recommend the inclusion of live yeast culture (Yea $\mathrm{Sacc}^{1026}$ ) at $6 \mathrm{~g} / \mathrm{animal} / \mathrm{day}$ as appropriate for field conditions.
\end{abstract}

Metabolic profile, sheep, machine milking, pasture, Yea Sacc ${ }^{1026}$

The use of dietary yeast cultures as a mechanism for manipulating rumen fermentation has been extensively investigated since the 1950s (Beeson and Perry 1952). These investigations are nowadays becoming even more important because of the ban on antibiotics in the EU. Products containing Saccharomyces cerevisiae vary widely in efficiency, primarily because of differences in strain and the viability of yeast cells. Numerous models have been designed to explain the effects of yeast in the rumen. Data indicate that supplementation of yeast in the ruminant diet may improve feed intake (Robinson and Garrett 1999; Williams et al. 1991), milk production (Abd El-Ghani 2004; Wang et al. 2001), weight gain (Salama et al. 2002), digestion (Jouany et al. 1998; Wohlt et al. 1991), numbers of anaerobic and cellulolytic bacteria (Newbold et al. 1995), ruminal pH value (Doreau and Jouany 1998; Jouany et al. 1998), and

Address for correspondence:

Dr. Tomislav Mašek

Department of Animal Nutrition

Faculty of Veterinary Medicine

University of Zagreb

10000 Zagreb, Croatia

Phone: Phone +385 12390274

Fax +385 12441390

E-mail: tomislav.masek@vef.h

http://www.vfu.cz/acta-vet/actavet.htm 
alter the patterns of volatile fatty acids (Arcos-Garcia et al. 2000) or even supply the animal with unknown growth factors (Girard and Dawson 1995). Nevertheless, the results of these studies have been variable and strongly influenced by ration composition (Newbold 1996; Dawson 1992). The influence of yeast supplementation on grazing animals has mainly been investigated in grazing steers (Olson et al. 1994a, 1994b; Arakaki et al. 2000). Much less is known about the effects of yeast supplementation on grazing dairy ewes, nevertheless in vitro trials (El Hassan et al. 1994) and trials on grazing steers may give justification for investigation.

According to FAO (1999) two-thirds of the world's sheep milk production is concentrated in the Mediterranean region. About $95 \%$ of sheep and goat milk is converted into highquality dairy products of regional or local importance (Boyazoglu and Morand-Fehr 2001). The breeding of dairy ewes suitable for the Mediterranean region of Croatia started in 1989 by crossing indigenous Istrian Sheep with high producing East Friesian dairy sheep (Mikulec et al. 2000). The aim of the breeding programme was to improve milk production without affecting the resistance of the animals to environmental conditions and to produce a dairy sheep breed that could be successfully grazed on low quality Mediterranean pastures. In the Mediterranean region of Croatia sheep husbandry is extensive and is based on grazing and therefore high producing animals may experience nutritional imbalances during summer droughts (Mikulec et al. 2000). In these conditions direct-fed microbials, such as live yeast cultures, may improve the productive performance of dairy ewes.

Since milk produced by dairy ewes in Croatia is used only for cheese making, the manipulation of the milk's chemical composition is an important objective. Therefore, the trial was designed to investigate the effect of live yeast culture on milk yield and the chemical composition of the milk of Istrian Sheep X East Friesian grazing dairy sheep during the machine milking period. Additionally we evaluated changes in blood biochemistry in order to test possible changes in metabolism.

\section{Materials and Methods}

Sixty crossbred Istrian Sheep $\times$ East Friesian dairy ewes were used in the lactation trial from the $40^{\text {th }}$ to the $180^{\text {th }}$ day of lactation (between February and July 2007), which is the usual period of machine milking in the region. All ewes were in second lactation. The sheep were divided into three groups on the $40^{\text {th }}$ day of lactation according to milk yield and body condition score recorded in the previous and current lactation. The ewes were milked twice daily (at 06:00 h and 17:00 h) in a double 24-stall parallel milking parlour. During the experiment, each group was kept in separate pens and separate paddocks between morning and evening milking. The sheep were randomly selected from a herd numbering 471 animals kept on the "Špin" dairy sheep farm located in the Istria Region, Republic of Croatia.

During the experimental period the animals received $1 \mathrm{~kg} /$ ewe/day of concentrate mixture, $0.3 \mathrm{~kg} / \mathrm{ewe} / \mathrm{day}$ lucerne hay and were allowed to graze from 7:00 h to 15:00 h and from 18:00 h to 21:00 h on rotational mixed grass pasture. The concentrate mixture was composed of corn (35\%), barley (20\%), sunflower meal (16\%), wheat bran $(16 \%)$, soybean meal $(8 \%)$, and vitamin-mineral mixture $(5 \%)$. The chemical composition of the concentrate mixture, hay and pasture are provided in Table 1. Fresh water was available ad libitum. Diets were formulated to meet or exceed NRC recommendations (NRC 1985).

Each group of ewes was randomly assigned to one of the dietary treatments: diet without live yeast culture ( control diet $=\mathrm{CD}$ ), diet with $3 \mathrm{~g} /$ day/sheep of live yeast culture (YC3) and diet with $6 \mathrm{~g} /$ day/sheep of live yeast culture (YC6). The live yeast culture (Yea Sacc ${ }^{1026}$; Alltech, Inc., Nicholasville, Kentucky, USA) was mixed with concentrate mixture and individually fed to ewes two times daily during morning and evening milking.

Samples of the concentrate, hay and pasture were collected throughout the experimental period for chemical composition analyses. The samples were ground and analyses were made according to the AOAC (1999). Neutral Detergent Fibre (NDF) and Acid Detergent Fibre (ADF) were determined by detergent procedure of Robertson and Van Soest (1981) and Van Soest et al. (1991), with alpha amylase (SIGMA-ALDRICH, Inc., USA) being added during NDF extraction. Sodium sulphite was not added.

The milk yield of each sheep was recorded weekly during two consecutive milkings $(6: 00 \mathrm{~h}$ and 17:00 h) by using recording jars in the milking parlour. Milk samples for composition analysis were taken biweekly until the end of the experiment. The samples were analysed for fat, protein, lactose, total solids and non-fat solids by a near infrared spectrophotometer using a Milkoscan FT 120 (Foss Electric, Denmark) and somatic cell count was determined using a Fossomatic 80 (Foss Electric, Denmark). The urea values were determined by an enzymatic colorimetric method using commercial kits of reagents (Herbos Dijagnostika doo, Sisak, Croatia). 
Table 1. Chemical composition and content of minerals and trace elements of concentrate mixture, pasture and hay

\begin{tabular}{|c|c|c|c|}
\hline $\begin{array}{l}\text { Chemical composition } \\
\text { (dry matter) }\end{array}$ & $\begin{array}{l}\text { Concentrate } \\
\text { mixture }\end{array}$ & $\begin{array}{l}\text { Mixed grass } \\
\text { pasture }\end{array}$ & $\begin{array}{c}\text { Lucerne } \\
\text { hay }\end{array}$ \\
\hline Dry matter & 88 & 21 & 89 \\
\hline Ash (\%) & 7.5 & 8.1 & 7.2 \\
\hline Crude fat $(\%)$ & 3.0 & 3.8 & 2.3 \\
\hline Crude protein $(\%)$ & 18.3 & 11.2 & 15.9 \\
\hline Crude fibre (\%) & 7.7 & 33.5 & 33.2 \\
\hline Neutral detergent fibre (\%) & 16.9 & 59.5 & 52.3 \\
\hline Acid detergent fibre (\%) & 7.1 & 36.4 & 38.6 \\
\hline Calcium (\%) & 0.67 & 0.38 & 1.28 \\
\hline Phosphorus (\%) & 0.77 & 0.30 & 0.29 \\
\hline Magnesium (\%) & 0.25 & 0.14 & 0.30 \\
\hline Sodium $(\%)$ & 0.22 & 0.19 & 0.12 \\
\hline Sulphur (\%) & 0.05 & 0.15 & 0.24 \\
\hline Potassium (\%) & 0.80 & 1.68 & 1.9 \\
\hline Chloride (\%) & 0.09 & 0.57 & 0.37 \\
\hline Zinc $\left(\mathrm{mg} \cdot \mathrm{kg}^{-1}\right)$ & 97 & 28 & 22 \\
\hline Manganese $\left(\mathrm{mg} \cdot \mathrm{kg}^{-1}\right)$ & 74 & 89 & 66 \\
\hline
\end{tabular}

Blood samples were collected on the $40^{\text {th }}, 110^{\text {th }}$ and $180^{\text {th }}$ day of lactation by puncture of the jugular vein, with the addition of heparin as an anticoagulant, prior to morning feeding. The blood plasma was separated by centrifugation and stored at $-20^{\circ} \mathrm{C}$ for a maximum of 60 days until assayed. Biochemical indicators were assayed by an automatic analyser (SABA 18, AMS, Italy) using commercial kits of reagents ("Herbos Dijagnostika d.o.o.", Sisak, Croatia). Enzyme assays were done at $37^{\circ} \mathrm{C}$, and alkaline phosphatase activity was measured at pH 10.5. Lipoprotein fractions were determined by electrophoresis in tapes of gelled cellulose-acetate $\left(\right.$ Cellogel $^{\circledR}$, MALTA Chemetron, Milan, Italy). Interrelation and absolute concentration of lipoprotein fractions were determined by Global-scan densitometer (MALTA Chemetron, Milan, Italy).

Normality of the distribution was tested with skewness and kurtosis tests, and Shapiro-Wilk test. The data not presenting Gaussian distribution (Triglycerides and AST) were normalized by log transformation. The PROC MIXED for repeated measurements of SAS was used for the analysis of variance (SAS 1992). Values recorded before the start of the experiment were used as covariates. Differences were considered at a significance level of $p<0.05$.

\section{Results}

Two ewes were eliminated from the final data analysis (Tables 2 and 3) because of a health problem that was not considered to be associated with the treatments. In both ewes this health problem was acute mastitis (one in the control and one in the YC6 group).

The values for milk yield and composition are presented in Table 2. Supplementation with live yeast culture only significantly increased the total milk yield during the experimental period in the YC6 group $(p<0.05)$ although YS3 also had a higher, but non-significantly, milk yield than the control group. Values for FCM and FPCM were higher in the treated groups $(p<0.05)$ than in the CD group. Fat yield and lactose yield significantly increased $(p<0.05)$ only in the YS6 group compared to the CD group.

The chemical composition of the milk was not influenced by the treatments with the exception of milk urea nitrogen that was significantly lower in the YC6 group $(p<$ 0.05 ). Values of milk yield and chemical composition did not differ from the respective values recorded in other animals in the herd (not included in the experiment) kept on the experimental farm.

The values of blood biochemistry are summarised in Table 3. Values for BHB were higher $(p<0.05)$ in the treated groups than in the CD group and NEFA values were higher $(p<0.05)$ in YC6 than in the control group. All other values concerning blood components were not significantly different between the groups. 
Table 2. Influence of yeast supplementation on average milk yield and composition ${ }^{1}$

\begin{tabular}{|c|c|c|c|}
\hline Indicator & $\mathrm{CD}(\mathrm{n}=19)$ & $\mathrm{YC} 3(\mathrm{n}=20)$ & YC6 $(n=19)$ \\
\hline \multicolumn{4}{|l|}{ Yield } \\
\hline Milk yield (g/day) & $929 \pm 110^{\mathrm{a}}$ & $996 \pm 107^{\mathrm{ab}}$ & $1072 \pm 171^{\mathrm{b}}$ \\
\hline $\mathrm{FCM}^{6.5}(\mathrm{~g} /$ day $)$ & $940 \pm 122^{\mathrm{a}}$ & $1116 \pm 122^{b}$ & $1221 \pm 200^{b}$ \\
\hline $\mathrm{FPCM}^{6.5 ; 5.8}(\mathrm{~g} /$ day $)$ & $931 \pm 115^{\mathrm{a}}$ & $1103 \pm 120^{\mathrm{b}}$ & $1204 \pm 193^{b}$ \\
\hline Fat yield (g/day) & $73 \pm 8^{\mathrm{a}}$ & $76 \pm 8^{a}$ & $85 \pm 15^{b}$ \\
\hline Protein yield (g/day) & $54 \pm 5$ & $56 \pm 6$ & $60 \pm 8$ \\
\hline Lactose yield (g/day) & $38 \pm 5^{\mathrm{a}}$ & $43 \pm 3^{\mathrm{ab}}$ & $47 \pm 8^{\mathrm{b}}$ \\
\hline \multicolumn{4}{|l|}{ Composition } \\
\hline Fat $(\%)$ & $7.8 \pm 0.5$ & $7.7 \pm 0.3$ & $8.0 \pm 0.1$ \\
\hline Protein $(\%)$ & $5.8 \pm 0.4$ & $5.7 \pm 0.3$ & $5.7 \pm 0.5$ \\
\hline Lactose $(\%)$ & $4.4 \pm 0.1$ & $4.4 \pm 0.2$ & $4.3 \pm 0.2$ \\
\hline Total solids (\%) & $19.0 \pm 0.8$ & $18.8 \pm 0.5$ & $19.5 \pm 0.8$ \\
\hline Non-fat solids (\%) & $11.2 \pm 0.4$ & $11.0 \pm 0.3$ & $11.1 \pm 0.6$ \\
\hline $\mathrm{SCC}\left(\mathrm{X} 10^{3} / \mathrm{ml}\right)$ & $402 \pm 169$ & $377 \pm 75$ & $490 \pm 15.2$ \\
\hline Urea N (mg/100ml) & $27.37 \pm 2.46^{\mathrm{a}}$ & $27.16 \pm 1.95^{\mathrm{a}}$ & $25.01 \pm 2.55^{b}$ \\
\hline
\end{tabular}

${ }^{1}$ Values represent means \pm standard deviation

a,b,c Values within rows with different superscripts are significantly different $(P<0.05)$

$\mathrm{CD}=$ control diet; $\mathrm{YC} 3=3 \mathrm{~g}$ of live yeast culture per day; $\mathrm{YC} 6=6 \mathrm{~g}$ of live yeast culture per day

$\mathrm{FCM}^{6.5}=$ fat corrected milk (6.5\% milk fat); $\mathrm{FPCM}^{6.5 ; 5.8}$ fat and protein corrected milk $(6.5 \%$ milk fat and $5.8 \%$ milk protein) (Pulina and Nudda 2004)

Table 3. Influence of yeast supplementation on blood plasma components ${ }^{1}$

\begin{tabular}{|l|c|c|c|}
\hline Biochemical indicators & CD $(\mathrm{n}=19)$ & YC3 $(\mathrm{n}=20)$ & YC6 $(\mathrm{n}=19)$ \\
\hline NEFA $\left(\mathrm{mmol} \cdot 1^{-1}\right)$ & $0.30 \pm 0.10^{\mathrm{a}}$ & $0.37 \pm 0.20^{\mathrm{ab}}$ & $0.38 \pm 0.12^{\mathrm{b}}$ \\
\hline BHB $\left(\mathrm{mmol} \cdot \mathrm{l}^{-1}\right)$ & $0.51 \pm 0.08^{\mathrm{a}}$ & $0.61 \pm 0.14^{\mathrm{b}}$ & $0.60 \pm 0.12^{\mathrm{b}}$ \\
\hline Urea $\left(\mathrm{mmol} \cdot \mathrm{l}^{-1}\right)$ & $7.40 \pm 1.39$ & $7.31 \pm 0.86$ & $6.94 \pm 1.17$ \\
\hline Triglycerides $\left(\mathrm{mmol} \cdot \mathrm{l}^{-1}\right)$ & $0.25 \pm 0.06$ & $0.24 \pm 0.06$ & $0.28 \pm 0.07$ \\
\hline Cholesterol $\left(\mathrm{mmol} \cdot \mathrm{l}^{-1}\right)$ & $1.92 \pm 0.23$ & $1.91 \pm 0.25$ & $1.96 \pm 0.16$ \\
\hline VLDL $(\%)$ & $6.3 \pm 4.1$ & $6.1 \pm 4.0$ & $7.7 \pm 4.0$ \\
\hline HDL $(\%)$ & $44.5 \pm 12.1$ & $46.6 \pm 8.7$ & $48.5 \pm 8.8$ \\
\hline LDL $(\%)$ & $49.1 \pm 12.6$ & $47.2 \pm 7.9$ & $43.7 \pm 10.0$ \\
\hline AST $\left(\mu \mathrm{kat} \cdot \mathrm{l}^{-1}\right)$ & $2.55 \pm 1.01$ & $2.78 \pm 1.30$ & $2.45 \pm 0.95$ \\
\hline ALT $\left(\mu \mathrm{kat} \cdot \mathrm{l}^{-1}\right)$ & $0.31 \pm 0.15$ & $0.23 \pm 0.12$ & $0.26 \pm 0.13$ \\
\hline GGT $\left(\mu \mathrm{kat} \cdot \cdot^{-1}\right)$ & $0.82 \pm 0.07$ & $1.07 \pm 0.20$ & $0.93 \pm 0.33$ \\
\hline ALP $\left(\mu \mathrm{kat} \cdot \mathrm{l}^{-1}\right)$ & $3.82 \pm 0.98$ & $3.75 \pm 1.43$ & $3.28 \pm 1.30$ \\
\hline
\end{tabular}

${ }^{1}$ Values represent means \pm standard deviation

a.b.c Values within rows with different superscripts are significantly different $(p<0.05)$

$\mathrm{CD}=$ control diet; $\mathrm{YC} 3=3 \mathrm{~g}$ of live yeast culture per day; $\mathrm{YC} 6=6 \mathrm{~g}$ of live yeast culture per day

\section{Discussion}

In our study, the inclusion of live yeast culture to the ewes' diet showed a positive effect on milk yield during lactation. This has also been reported in dairy cows (Wang et al. 2001; Robinson and Garrett 1999; Wohlt et al. 1991) and in dairy goats (Abd El-Ghani 2004; Stella et al. 2007; Reklewska et al. 2000). In contrast, other authors found no improvement of milk yield in dairy cows (Soder and Holden 1999; Arambel and Kent 1990; Swartz et al. 1994), dairy goats (Hadjipanayiotou et al. 1997; Giger-Reverdin et al. 1996) or in dairy ewes (Hadjipanayiotou et al. 1997). These results confirm that the effects of live yeast 
administration were strongly influenced by diet composition. Although many authors stated that live yeast cultures are most efficient when animals are fed diets poor in nutrient supply (Jouany et al. 1998; Plata et al. 1994) or high concentrate diets overloaded with energy (Williams et al. 1991; Zelenak et al. 1994), in some cases it is difficult to find a correlation between diet composition and the results of yeast supplementation. The animals in our trial were fed relatively high levels of concentrate $(1 \mathrm{~kg} /$ animal/day) which could lead to improved buffering capacity in the rumen. Our results were also dose-dependent because $3 \mathrm{~g}$ of live yeast cultures per day was not efficient enough to maintain a constantly higher milk yield than in the control group. Similar results were obtained by Abd El-Ghani (2004) with 3 and $6 \mathrm{~g}$ of live yeast cultures per day fed to dairy goats.

Due to the higher amount of total solids in sheep milk, compared to cows and goats, we expected that the supplementation of yeast may be more efficient in changing milk composition. However, the milk fat content was not significantly higher in the treated groups than in the control group, which is in agreement with Piva et al. (1993) who stated that the common result of yeast supplementation to dairy cows is only a slight (nonsignificant) increase in the milk fat content. Hadjipanayiotou et al. (1997) and Stella et al. (2007) also reported no increase in milk fat content in dairy goats. In Damascus dairy ewes Hadjipanayiotou et al. (1997) found no influence of live yeast administration on milk composition, although in their study the yeast was steam-pelleted with no report on cell viability. On the contrary, Abd El-Ghani (2004), Giger-Reverdin et al. (1996) and Mašek et al. (2008) found increased milk fat values in dairy goats and ewes. Milk protein and lactose values did not differ between the treatments, which was also noticed by the majority of authors (Stella et al. 2007; Giger-Reverdin et al. 1996). Milk urea values were significantly lower in the group fed 6 g per day. Harrison et al. (1988) reported a much lower concentration of rumen ammonia $\mathrm{N}$ after yeast supplementation, which is in agreement with the results from Erasmus et al. (1992), who found that the mean concentration of rumen ammonia decreased by $10 \%$ after YC supplementation. Erasmus et al. (1992) explained these reduced concentrations of ammonia in the rumen as the result of increased incorporation of ammonia into microbial protein and the direct result of stimulated microbial activity which could explain lower blood and milk urea values in our experiment.

We found significantly higher NEFA and BHB values in the treated groups, which is in agreement with Giger-Reverdin et al. (1996) and Quigley et al. (1992). Increase in NEFA values could be explained by increased mobilisation of fat tissue caused by live yeast supplementation, which was also noted in dairy goats (Giger-Reverdin et al. 1996). According to Quigley et al. (1992), the increased ruminal butyrate was at least partially responsible for increased $\mathrm{BHB}$ values. Triglycerides and cholesterol values tended to be higher in the treated groups, which was also noted by Pysera and Opalka (2001). The same authors also found, in contrast to our results, differences in lipoprotein fractions. All biochemistry values were within the normal reference range for lactating dairy ewes (Mašek et al. 2007; Roubies et al. 2006; Yokus and Cakir 2006; Dubreuil et al. 2005).

Literature dealing with yeast supplementation in grazing animals is scarce and to our knowledge, involves mainly steers. Various authors found an increased number of protozoa (Arakaki et al. 2000), increased live weight gain (Combellas et al. 2002) and increased degradation and digestibility (Olson et al. 1994a, 1994b). According to most authors, micro-population plays a key role in the mode of action of yeast in the rumen (Dawson 1992; Wallace and Newbold 1992; Newbold et al. 1995). El Hassan et al. (1994) observed that Yea Sacc ${ }^{1026}$ stimulated the total bacterial number in a rumen-simulating fermentor (Rusitec) when the basal diet was grass and increased, but not significantly, the number of cellulolytic bacteria. This increase in the number of bacteria, with a diet of grass, could explain the better performance of the dairy ewes in our trial. 
We concluded that the supplementation of live yeast culture (Yea Sacc ${ }^{1026}$ ) had a significant beneficial effect on the milk yield of grazing dairy sheep, fed pasture and concentrate mixture during the milking period. The significant results were probably a result of the interactions between yeast culture supplementation and diet composition. Since the influence was dose-dependent, we could recommend $6 \mathrm{~g}$ per day for inclusion in dairy sheep diets. Additional studies under different feeding conditions and in earlier stages of lactation should clarify the influence of live yeast supplementation in the diets of grazing dairy ewes and define the dietary situations in which it may be beneficial.

\section{Vliv živé kultury kvasinek (Saccharomyces cerevisiae) na produkci a složení mléka, a na biochemické ukazatele v krvi pastevně chovaných ovcí mléčného plemene během období laktace se strojním dojením}

Předmětem této studie bylo zhodnocení vlivu podávání krmiva obohaceného o živou kulturu kvasinek (Saccharomyces cerevisiae) na produkci a složení mléka, a na biochemické ukazatele krve ovcí mléčného plemene v období strojního dojení. Ovcím v kontrolní skupině (CD) byla podávána krmná dávka složená z jadrného krmiva a sena, pastva byla dvakrát denně. Pokusným zvíratům druhé (YS3) a třetí (YS6) skupiny byla podávána stejná dieta doplněná o 3 resp. 6 g živé kultury kvasinek (Yea Sacc ${ }^{1026}$ ). U zvířat, kterým bylo krmivo obohaceno o kulturu kvasinek, se významně zvýšily $(p<0.05)$ hodnoty pro mléko s upraveným obsahem tuku (FCM) (1221 resp. $1116 \mathrm{~g} /$ den u pokusné skupiny YS6 resp. YS3 a 940 g/den u kontrolní skupiny CD) a hodnoty pro mléko s upraveným množstvím tuku a proteinu (FPCM) (1204 a $1103 \mathrm{~g} /$ den u pokusných skupin YS6 resp. YS3 a 931 $\mathrm{g} /$ den u kontroly CD). Hodnoty dojivosti, tučnosti mléka a obsah laktózy byly významně vyšší $(p<0.05)$ pouze v YS6 skupině ve srovnání s CD skupinou. Hodnoty dojivosti u zvířat v YS6 skupině byly trvale zvýšené v porovnání s kontrolní skupinou, zatímco dojivost u ovcí v YS3 byla během období strojního dojení variabilní. Jednotlivé složky mléka nebyly významně ovlivněny přídavkem kultury kvasinek do krmiva, pouze u ovcí ve skupině YC6 byla zjištěna nižší hodnota močoviny $(p<0.05)$ a zároveň došlo ke zvýšení $(p<0.05)$ obsahu nenasycených mastných kyselin (NEFA). V obou pokusných skupinách bylo pozorováno zvýšení $(p<0.05)$ obsahu $\beta$-hydroxy-butyrátu $(\mathrm{BHB})$ ve srovnání s kontrolní skupinou. Další biochemické ukazatele měřené v krvi nebyly přidáním kvasinek do krmiva ovlivněny.

Z našeho experimentu vyplývá, že za těchto podmínek pokusu má přídavek živé kultury kvasinek výrazný vliv na produkci mléka a metabolismus ovcí mléčného plemene během období strojního dojení. Na základě dalších výsledků lze zahrnutí živé kultury kvasinek (Yea $\operatorname{Sacc}^{1026}$ ) do krmné dávky pastevně chovaných ovcí pokládat za příznivé a to v množství $6 \mathrm{~g} / \mathrm{zvír} \mathrm{r} / \mathrm{den}$.

\section{Acknowledgement}

The study was supported by the Ministry of Science, Education, and Sport of the Republic of Croatia, in the project "The influence of nutraceuticals on the health and performance of food animals" No. 053-0532265-2244. We are also grateful to the "Kušić Promet" feed factory for providing us with dairy sheep premix (Kuškovit) and the "Špin" dairy sheep farm.

\section{References}

ABD EL-GHANI AA 2004: Influence of diet supplementation with yeast culture (Saccharomyces cerevisiae) on performance of Zaraibi goats. Small Ruminant Res 52: 223-229

AOAC 1999: Association of Official Analytical Chemists. Official Methods of Analysis, 16 ${ }^{\text {th }}$ ed. AOAC International Gaithersburg, MD., p. 111

ARAKAKI LC, STAHRINGER RC, GARRETT JE, DEHORITY BA 2000: The effects of feeding monensin and yeast culture, alone or in combination, on the concentration and generic composition of rumen protozoa in steers fed on low-quality pasture supplemented with increasing levels of concentrate. Anim Feed Sci Technol 84: $121-127$ 
ARCOS-GARCIA JL, CASTREJON FA, MENDOZA GD, PEREZ-GAVILAN EP 2000: Effects of two commercial yeast cultures with Saccharomyces cerevisiae on ruminal fermentation and digestion in sheep fed sugar cane tops. Livest Prod Sci 63: 153-157

ARAMBEL MJ, KENT BA 1990: Effect of yeast culture on nutrient digestibility and milk yield response in early to midlactation dairy cows. J Dairy Sci 73: 1560-1563

BEESON WM, PERRY TW 1952: Balancing the nutritional deficiencies of roughages for beef steers. J Anim Sci 11: 501-509

BOYAZOGLU J, MORAND-FEHR P 2001: Mediterranean dairy sheep and goat products and their quality. A critical review. Small Ruminant Res 40: 1-11

COMBELLAS J, JACQUELINE S, TESORERO M, GABALDON L 2002: Response of yearling cattle to the addition of yeast culture to a diet of pasture, poultry litter and wheat middlings. Zootec Trop 20: 373-381

DAWSON KA 1992: Current and future role of yeast culture in animal production: A review of research over the past six years. In: LYONS TP (Ed.): Proceedings of Alltech's $8^{\text {th }}$ annual symposium, Nicholasville, Kentucky, pp. 1-23

DUBREUIL P, ARSENAULT J, BELANGER D 2005: Biochemical reference ranges for groups of ewes of different age. Vet Rec 156: 636-638

DUFFIELD T, BAGG R, KELTON D, DICK P, WILSON J 2003: A field study of dietary interactions with monensin on milk fat percentage in lactating dairy cattle. J Dairy Sci 86: 4161-4166

DOREAU M, JOUANY JP 1998: Effect of a Saccharomyces cerevisiae on nutrient digestion in lactating dairy cow. J Dairy Sci 81: 3214-3221

EL HASSAN SM, NEWBOLD CJ, WALLACE RJ 1994: The effect of yeast culture addition to diets of grass and grass silage on rumen bacterial numbers. Anim Prod 58: 451

ERASMUS LJ, BOTHA PM, KISTNER A 1992: Effect of yeast culture supplement on production, rumen fermentation, and duodenal nitrogen flow in dairy cows. J Dairy Sci 75: 3056-3065

FAO 1999: Food and Agriculture Organization. Agricultural Statistics. Rome, 577 p.

GIGER-REVERDIN S, BEZAULT N, SAUVANT D, BERTIN G 1996: Effects of a probiotic yeast in lactating ruminants: interaction with dietary nitrogen level. Anim Feed Sci Technol 63: 149-162

GIRARD ID, DAWSON KA 1995: Stimulation of ruminal bacteria by different fractions derived from cultures of Saccharomyces cerevisiae strain 1026. J Anim Sci 73 (Suppl): 264

HADJIPANAYIOTOU M, ANTONIOU I, PHOTIOU A 1997: Effects of the inclusion of yeast culture on the performance of dairy ewes and goats and the degradation of feedstuffs. Livest Prod Sci 48: 129-134

HARRISON GA, HEMKEN RW, DAWSON KA, HARMON RJ, BARKER KB 1988: Influence of addition of yeast culture supplement to diets of lactating cows on ruminal fermentation and microbial populations. J Dairy Sci 71: 2967-2975

JOUANY JP, MATHIEU F, SENAUD J, BOHATIER J, BERTIN G, MERCIER M 1998: The effect of Saccharomyces cerevisiae and Aspergilus oryzae on the digestion of the cell wall fraction of a mixed diet in defaunated and refaunated sheep rumen. Reprod Nutr Dev 38: 401-416

MAŠEK T, MIKULEC Ž, VALPOTIĆ H, PAHOVIĆ S 2007: Blood biochemical parameters of crossbred Istrian $\mathrm{X}$ East Friesian dairy ewes: relation to milking period. Ital J Anim Sci 6: 281-288

MAŠEK T, MIKULEC Ž, VALPOTIĆ H, KUSCE L. MIKULEC N, ANTUNAC N 2008: The influence of live yeast cells (Saccharomyces cerevisiae) on the performance of grazing dairy sheep in late lactation. Vet Arh 78: 95-104

MIKULEC K, SUŠIĆ V, MIKULEC Ž, ŠERMAN V 2000: Breeding of dairy sheep for the Mediterranean region of Croatia. Options Mediterraneennes. Serie A. Semin Mediterr 43: 79-86

NEWBOLD CJ, WALLACE RJ, CHEN XB, McINTOSH FM 1995: Different strains of Saccharomyces cerevisiae differ in their effects on ruminal bacterial numbers in vitro and in sheep. J Anim Sci 73: 1811-1818

NEWBOLD CJ 1996: Probiotics for ruminants. Ann Zootech 45 (Suppl): 329-335

NRC 1985: Nutrient requirements of sheep. $6^{\text {th }}$ rev. ed. Committee on Animal Nutrition, National Research Council, 112 p. (ISBN 0309035961)

OLSON KC, CATON JS, KIRBY DR, NORTON PL 1994a: Influence of yeast culture supplementation and advancing season on steers grazing mixed-grass prairie in the northern Great Plains: II. Ruminal fermentation, site of digestion, and microbial efficiency. J Anim Sci 72: 2158-2170

OLSON KC, CATON JS, KIRBY DR, NORTON PL 1994b: Influence of yeast culture supplementation and advancing season on steers grazing mixed-grass prairie in the northern Great Plains: I. Dietary composition, intake, and in situ nutrient disappearance. J Anim Sci 72: 2149-2157

PIVA G, BELLADONNA S, FUSCONI G, SICBALDI F 1993: Effects of yeast on dairy cow performance, ruminal fermentation, blood components, and milk manufacturing properties. J Dairy Sci 76: 2717-2722

PLATA FP, MENDOZA GD, BARCENA-GAMA MJR, GONZALEZ MS 1994: Effect of a yeast culture (Saccharomyces cerevisiae) on neutral detergent fiber digestion in steers fed oat straw based diets. Anim Feed Sci Technol 49: 203-210

PULINA G, NUDDA A 2004: Milk production. In: PULINA G (Ed.): Dairy sheep nutrition. CABI Publishing, Oxfordshire, pp. 1-13

PYSERA B, OPALKA A 2001: Lipids and lipoproteins in blood serum of calves receiving Yea-Sacc1026 dietary supplement. J Anim Feed Sci 10: 77-82 
QUIGLEY JD, WALLIS LB, DOWLEN HH, HEITMANN RN 1992: Sodium bicarbonate and yeast culture effects on ruminal fermentation, growth, and intake in dairy calves. J Dairy Sci 75: 3531-3538

REKLEWSKA B, RYNIEWICZ Z, KRZYZEWSKI J, KARASZEWSKA A, GÓRALCZYK M, ZDZIARSKI K, NALECZ-TARWACKA T, STRZALKOWSKA N 2000: Dietary manipulation of milk protein content in goats. Ann Wars Agric Univ Anim Sci 35: 133-143

ROBERTSON JB, VAN SOEST PJ 1981: The detergent system of analysis and its application to human foods In: JAMES WPT, THEANDER O (Eds.): The analysis of dietary fiber in food. Marcel Dekker, New York, pp. 123-158

ROBINSON PH, GARRETT JE 1999: Effect of yeast culture (Saccharomyces cerevisiae) on adaptation of cows to postpartum diets and on lactational performance. J Anim Sci 77: 988-999

ROUBIES N, PANOUSIS N, FYTIANOU A, KATSOULOS PD, GIADINIS N, KARATZIAS H 2006: Effects of age and reproductive stage on certain serum biochemical parameters of Chios sheep under Greek rearing conditions. J Vet Med A-Physiol Pathol Clin Med 53: 277-281

SALAMA AAK, CAJA G, GARIN D, ALBANELL E, SUCH X, CASALS R 2002: Effects of adding a mixture of malate and yeast culture (Saccharomyces cerevisiae) on milk production of Murciano-Granadina dairy goats. Anim Res 51: 295-303

SAS Institute 1992: SAS User's Guide: Statistics. SAS Inst. Inc., Cary, NC

SODER KJ, HOLDEN LA 1999: Dry matter intake and milk yield and composition of cows fed yeast prepartum and postpartum. J Dairy Sci 82: 605-610

STELLAAV, PARATTE R, VALNEGRI L, CIGALINO G, SONCINI G, CHEVAUX E, DELL ORTO V, SAVOINI G 2007: Effect of administration of live Saccharomyces cerevisiae on milk production, milk composition, blood metabolites, and faecal flora in early lactating dairy goats. Small Ruminant Res 67: 7-13

SWARTZ DL, MULLER LD, ROGERS GW, VARGA GA 1994: Effect of yeast cultures on performance of lactating dairy cows: a field study. J Dairy Sci 77: 3073-3080

VAN SOEST PJ, ROBERTSON JB, LEWIS BA 1991: Methods for dietary fiber, neutral detergent fiber and nonstarch polysaccharides in relation to animal nutrition. J Dairy Sci 74: 3583-3597

WALLACE RJ, NEWBOLD CJ 1992: Probiotics for ruminants. In: FULLER R (Ed.): Probiotics: The scientific basis. Chapman and Hall, London, pp. 317-353

WANG Z, EASTRIDGE ML, QIU X 2001: Effects of forage neutral detergent fiber and yeast culture on performance of cows during early lactation. J Dairy Sci 84: 204-212

WILLIAMS PE, TAIT CA, INNES GM, NEWBOLD CJ 1991: Effects of the inclusion of yeast culture (Saccharomyces cerevisiae plus growth medium) in the diet of dairy cows on milk yield and forage degradation and fermentation patterns in the rumen of steers. J Anim Sci 69: 3016-3026

WOHLT JE, FINKELSTEIN AD, CHUNG CH 1991: Yeast culture to improve intake, nutrient digestibility and performance by dairy cattle during early lactation. J Dairy Sci 74: 1395-1400

YOKUS B, CAKIR UD 2006: Seasonal and physiological variations in serum chemistry and mineral concentrations in cattle. Biol Trace Elem Res 109: 255-266

ZELENAK I, JALČ V, KMET V, SIROKA P 1994: Influence of diet and yeast supplement on in vitro ruminal characteristic. Anim Feed Sci Technol 49: 211-221 